\title{
Main prognostic factors and physical therapy modalities associated with functional recovery in patients with peripheral facial paralysis
}

\author{
Principais fatores prognósticos e modalidades fisioterapêuticas associados à recuperação \\ funcional em pacientes com paralisia facial periférica
}

Principales factores pronósticos y modalidades de fisioterapia relacionadas a la recuperación funcional de pacientes con parálisis facial periférica

\section{Angela Juliana Cappeli', Hélio Rubens de Carvalho Nunes², Mônica de Oliveira Orsi Gameiro³, Rodrigo Bazan ${ }^{4}$, Gustavo José Luvizutto ${ }^{5}$}

\begin{abstract}
I Patients with peripheral facial paralysis (PFP) have some degree of recovery. The aim of this study was to evaluate prognostic factors and physical therapy modalities associated with functional recovery in patients with PFP. This is a cohort study with 33 patients. We collected the following variables of patients who underwent treatment at the rehabilitation center: age, sex, risk factors, affected side, degree of facial paralysis (House-Brackmann scale), start of rehabilitation, and therapy modality (kinesiotherapy only; kinesiotherapy with excitomotor electrotherapy; and kinesiotherapy with excitomotor electrotherapy and photobiomodulation therapy). The outcomes were: degree of facial movement (House-Brackmann) and face scale applied 90 days after treatment. Degree of PFP was associated with functional recovery ( $R R=0.51,95 \% \mathrm{Cl}$ : 0.51-0.98; $p=0.036$ ). The facial movement was associated with the time to start rehabilitation ( $r=-0.37 ; p=0.033$ ). Lower facial comfort was observed among women, worse ocular comfort was associated with diabetes mellitus, worse tear control with prior PFP, and worse social function with the degree of PFP. Our results indicate that the all modalities present in this study showed the same result in PFP. Recovery of PFP was
\end{abstract}

associated with degree of nerve dysfunction, the length of time to onset of rehabilitation, female sex, hypertension, diabetes mellitus, and previous PFP, all of which were associated with worse outcomes on the face scale.

Keywords | Facial Paralysis; Bell's Palsy; Physical Therapy; Prognosis.

RESUMO I Os pacientes com paralisia facial periférica (PFP) apresentam diversos graus de recuperação. O objetivo deste estudo foi avaliar os fatores prognósticos e as modalidades fisioterapêuticas associados à recuperação funcional em pacientes com PFP. Trata-se de um estudo coorte prospectiva de 33 pacientes. Foram coletadas variáveis de pacientes submetidos ao tratamento no centro de reabilitação: idade, sexo, fatores de risco, lado afetado, grau de paralisia facial (escala de HouseBrackmann), início da reabilitação e modalidade de terapia (cinesioterapia; cinesioterapia associada à eletroterapia; cinesioterapia associada à eletroterapia e terapia de fotobiomodulação). Os desfechos foram: grau de movimento facial (House-Brackmann) e face scale aplicados 90 dias após o tratamento. O grau de PFP foi

Study conducted at Faculdade de Medicina de Botucatu. Work presented at XX Congresso Internacional de Fisioterapia. "Universidade Estadual Paulista "Júlio de Mesquita Filho" (Unesp) - Botucatu (SP), Brazil. E-mail: juliana.capelli@yahoo.com.br. Orcid: 0000-0003-0867-6470

Universidade Estadual Paulista "Júlio de Mesquita Filho" (Unesp) - Botucatu (SP), Brazil. E-mail: hrcn@outlook.com.br. Orcid: 0000-0002-7806-1386

3Universidade Estadual Paulista "Júlio de Mesquita Filho” (Unesp) - Botucatu (SP), Brazil. E-mail: orsigam@yahoo.com.br. Orcid: 0000-0002-1071-5988

«Universidade Estadual Paulista “Júlio de Mesquita Filho” (Unesp) - Botucatu (SP), Brazil. E-mail: bazan.r@terra.com.br. Orcid: 0000-0003-3872-308X

${ }^{5}$ Universidade Federal do Triângulo Mineiro (UFTM) - Uberaba (MG), Brazil. E-mail: gustavo.luvizutto@uftm.edu.br. Orcid: 0000-0002-6914-7225 
associado à recuperação funcional ( $R R=0,51,95 \%$ IC: 0,51-0,98; $p=0,036)$. O movimento facial foi associado com o tempo para iniciar a reabilitação $(r=-0,37 ; p=0,033)$. Menor conforto facial foi observado entre as mulheres, pior conforto ocular em indivíduos com diabetes mellitus, pior controle lacrimal em indivíduos com PFP prévia e pior função social com o grau de PFP. Todas as modalidades apresentadas neste estudo tiveram o mesmo resultado na PFP. A recuperação da PFP foi associada ao grau de disfunção nervosa, ao tempo de início da reabilitação, ao sexo feminino, à hipertensão arterial sistêmica, ao diabetes mellitus e à PFP prévia, todos associados a piores desfechos na face scale. Descritores I Paralisia Facial; Paralisia de Bell; Fisioterapia; Prognóstico.

RESUMEN I Los pacientes con parálisis facial periférica (PFP) tienen diferentes grados de recuperación. El presente estudio tuvo como objetivo evaluar los factores pronósticos y las modalidades de fisioterapia relacionadas a la recuperación funcional de pacientes con PFP. Este es un estudio de cohorte prospectivo con 33 pacientes. Se recogieron las siguientes variables de pacientes sometidos a tratamiento en el centro de rehabilitación: edad, sexo, factores de riesgo, lado afectado, grado de parálisis facial (escala de House-Brackmann), inicio de la rehabilitación y modalidad de terapia (kinesioterapia, kinesioterapia asociada a la electroterapia, kinesioterapia asociada a la electroterapia y terapia de fotobiomodulación). Los resultados fueron: grado de movimiento facial (House-Brackmann) y face scale, aplicados 90 días después del tratamiento. El grado de PFP se asoció con la recuperación funcional ( $R R=0,51,95 \%$ IC: 0,51-0,98; $p=0,036)$. El movimiento facial se asoció con el tiempo para comenzar la rehabilitación ( $r=-0,37 ; p=0,033$ ). Se observó menor comodidad facial entre las mujeres, peor comodidad ocular en personas con diabetes mellitus, peor control lagrimal en individuos con PFP previa y peor función social con el grado de PFP. Todas las modalidades presentadas en este estudio tuvieron el mismo resultado en PFP. La recuperación de la PFP se asoció con el grado de disfunción nerviosa, el tiempo inicial de la rehabilitación, el sexo femenino, la hipertensión arterial sistémica, la diabetes mellitus y la PFP previa, todos asociados con peores resultados en face scale.

Palabras clave | Parálisis Facial; Parálisis de Bell; Fisioterapia; Pronóstico.

\section{INTRODUCTION}

Peripheral facial paralysis (PFP) is characterized by reduction or interruption of nerve conduction of the seventh cranial nerve to the muscles of the face, resulting in partial or complete paralysis of these muscles ${ }^{1,2}$. The incidence of PFP in the world population is approximately 20 to 30 cases per 100,000 people and is more prevalent in older adults ${ }^{3-7}$.

$\mathrm{PFP}$ is often idiopathic (i.e., Bell's palsy), but infection, inflammation, trauma, surgery, and tumor are additional causes $^{8-10}$. The main risk factors for PFP are diabetes mellitus, pregnancy and postpartum, cold weather, hypertension, age, and immunodeficiency syndromes. Diagnostic criteria for PFP include sudden onset of unilateral complete or partial paralysis of motility of the facial muscles with no signs or symptoms of central nervous system (CNS) injury. PFP may be accompanied by disturbances in taste, salivation, and tearing; hyperacusis and hypoesthesia in the external auditory canal; and functional deficits in oral functions such as speech, chewing, sucking, swallowing, and lip hold. The degree of motor impairment is assessed via the House-Brackmann scale to quantify the degree of paresis at diagnosis ${ }^{11-18}$.
The prognosis for a patient with PFP depends on several factors, such as age, type of injury, etiology, nerve nurturing, neuromuscular impairment, therapeutic use, and precocity of rehabilitation treatment ${ }^{19}$. In general, all patients exhibit some degree of recovery, even without treatment, but treatment may accelerate and optimize recovery. Most cases of PFP require treatment with medication and physical and speech therapy. Studies suggest that treatments with antivirals, steroids, acyclovir, botulinum toxin, electrotherapy, and vitamin B12 are effective. There is also some evidence for the effectiveness of physical therapy or electrotherapy, but there are a few clinical trials for patients with $\mathrm{PFP}^{19-21}$.

Several patients with PFP perform different treatment modalities and present different associated risk and clinical factors. There is a gap in the literature in establishing which factors (treatments and clinical factors) are decisive in predicting worse or better outcome in the long term after PFP. Thus, the aim of this study was to evaluate the main prognostic factors and physical therapy modalities involved in the functional recovery of patients with PFP. The main hypothesis was that different types of treatment, comorbidities, anthropometric and clinical characteristics may interfere with long-term functional outcomes. 


\section{METHODOLOGY}

\section{Study design, setting and participants}

This study involved a retrospective and prospective cohort of patients admitted to the rehabilitation center of the Hospital of the Botucatu School of Medicine (HC-FMB) from January 2010 to January 2015. The study protocol was approved by the Research Ethics Committee of the Botucatu School of Medicine, UNESP (CAAE: 50507215.7.0000.5411). All participants or their legal representatives were aware of the study objectives and provided written informed consent.

\section{Eligibility criteria}

We evaluated individuals diagnosed with idiopathic PFP. Patients who presented with PFP secondary to cerebrovascular disease, brain tumor, Guillain-Barré syndrome, or parotitis were excluded. In addition, patients with otogenic facial paralysis due to otitis media or mastoiditis and patients with PFP due to trauma, surgery, or tumor were also excluded.

\section{Measurements}

We collected several variables from the electronic medical records of patients with PFP who underwent treatment at the rehabilitation center, including age, sex, risk factors, affected side, degree of facial paralysis (HouseBrackmann scale), onset of PFP, onset of rehabilitation, and physical therapy modality.

The primary outcome was the degree of full or partial return of facial movement as measured by the House-Brackmann scale. The House-Brackmann scale grades the level of facial nerve injury in patients with $\mathrm{PFP}$ by evaluating the frontal muscles, the orbicularis of the eyes and mouth, the Risorius zygomatic muscle, and muscles of the upper lip and nose. The HouseBrackmann scale ranges from grade I to grade VI, with grade VI representing the most severe facial nerve paralysis ${ }^{22}$.

Secondary outcomes were the scores on the six areas measured by the face scale 90 days after initial diagnosis. The face scale assesses movements on both sides of the face, the occurrence of certain events, and how the patient feels due to facial problems. The face scale is divided into six areas: facial movement, facial comfort, oral function, ocular comfort, lacrimal control, and social function. The total score ranges from 0 (worst) to 100 (best) ${ }^{23}$.

\section{Independent variables}

All participants were included to the facial rehabilitation protocol applied in the Botucatu Medical School. Patients in this study received one of three treatment types: (1) kinesiotherapy only; (2) kinesiotherapy with excitomotor electrotherapy; (3) kinesiotherapy with excitomotor electrotherapy and photobiomodulation therapy.

Kinesiotherapy consisted of active exercises (brow lift, gentle eye closure, open mouse smile, snarl, and lip pucker) and massage therapy in all muscles of the face in the direction of the fiber. Five sets of five repetitions of each exercise were performed with an interval of 1 minute between them to avoid synkinesis. The total of this modality was 20 minutes ${ }^{24}$.

Excitomotor electrotherapy was performed with Bernard's diadynamic currents with the positive pole positioned on the external acoustic meatus and the negative pole positioned on the frontal muscle. The metallic aluminum electrodes used had the standard size of $4.3 \mathrm{~cm} \times 11.3 \mathrm{~cm}$, covered by a damp sponge. The following parameters were used: 3 minutes of diphase fixe (DF) current (frequency of $100 \mathrm{~Hz}$; pulse of $10 \mathrm{~ms}$ and no intervals), 3 minutes of simple impulse (MF-monophase) current (frequency of $50 \mathrm{~Hz}$; pulse of $10 \mathrm{~ms}$; and intervals of equal duration), and 3 minutes of short periods (CP) current (MF and DF alternating $1 \mathrm{~s}$ ). The adjustment of the amplitude of the current for the groups was done in a standardized way, increasing 1 $\mathrm{mA}$ of current every second until the participant report strong but comfortable paresthesia. Stimulation started with positive pole with aim to guide fluid removal by endosmosis in acute phase of PFP and the polarities were reversed after 15 days $^{25,26}$.

For photobiomodulation therapy, a gallium-arsenide diode ( $\mathrm{GaAs})$ laser $(830 \mathrm{~nm})$ which had the following specifications: $830 \mathrm{~nm}$ wavelength and $100 \mathrm{~mW}$ output power and $0.1 \mathrm{~cm}$ diameter, average energy density of $4 \mathrm{~J} / \mathrm{cm} 2$, frequency of $1 \mathrm{KHz}$, and a duty cycle of $80 \%{ }^{27}$. In all cases, the laser was in direct contact with the superficial roots of the facial nerve on the affected side and was applied for $15 \mathrm{~s}$ per point for 8 points. The irradiance was 12.7 watts $/ \mathrm{cm}$ and the energy fluence (energy per unit areas incident on the skin) was 191 joules $/ \mathrm{cm}^{27}$. 
The three treatment types were performed twice per week for three months. All patients received steroids/ antivirals within 48 hours of onset of symptoms of PFP.

\section{Confounding factors}

The main confounding factors that were evaluated in this study include age, sex, facial laterality, risk factors (hypertension, diabetes mellitus, smoking habit, alcoholism, hypercholesterolemia, hypothyroidism) previous facial paralysis, facial paralysis upon awakening, degree of paralysis at initial evaluation, and time between diagnosis and start of rehabilitation.

\section{Statistical analysis}

The relative risk (RR) of recovery of full movement in six months, as assessed by the House-Brackmann scale, was estimated by a Cox multiple logistic regression model adjusted for the degree of facial paralysis. The association between the different physical therapy treatment groups and the face scale scores was analyzed by the non-parametric Kruskal-Wallis test; no corrections for potential confounders were used in this analysis due to the small sample size. Results with $\mathrm{p}<0.05$ were considered statistically significant. All analyses were performed in SPSS version 21.0 (IBM, Armonk, NY, USA).

\section{RESULTS}

In total, 103 patients were screened, of which 70 were excluded (central facial paralysis: 25 ; parotitis: 17 ; brain tumor: 5; otitis media or mastoiditis: 13; traumatic facial paralysis: 5; surgical facial paralysis: 3; tumor facial paralysis: 2), thus, 33 patients were included in the study (11 - kinesiotherapy only; 12 - kinesiotherapy with excitomotor electrotherapy, and 10 - kinesiotherapy with excitomotor electrotherapy and photobiomodulation therapy) and completed the clinical follow-up (Figure 1).



Figure 1. Flowchart 
The clinical data and outcomes of the total of patients and the comparison between the groups of interventions are described in Table 1.

The RR of full recovery of facial movement at six months was associated with the degree of facial paralysis on admission ( $R R=0.51,95 \% \mathrm{CI}$ : 0.51-0.98; $\mathrm{p}=0.036)$.
No other clinical and anthropometric variables were related to the RR of full recovery (Table 2).

The Cox multiple regression model, which was adjusted for the degree of facial paralysis on admission, revealed no statistically significant difference in the effect of treatment on recovery (Table 3 ).

Table 1. Demographic and clinical characteristics between treatment groups

\begin{tabular}{|c|c|c|c|c|}
\hline Variable & & & & \\
\hline Age (years) $)^{(1)}$ & $49(32-64)$ & $59(17-80)$ & $36(20-73)$ & $0.711^{(2)}$ \\
\hline Female: Male & $100: 0$ & $62: 39$ & $60: 40$ & $0.298^{(1)}$ \\
\hline Right: Left & $40: 60$ & $46: 54$ & $40: 60$ & $0.64^{(1)}$ \\
\hline Time between diagnosis and rehabilitation (days) & $6(3-30)$ & $15(2-60)$ & $4(1-10)$ & $0.098^{(2)}$ \\
\hline Full recovery in six months (\%) & 40 & 54 & 60 & $0.879^{(2)}$ \\
\hline Total & $65(60-71)$ & $67(42-71)$ & $71(62-71)$ & $0.361^{(2)}$ \\
\hline
\end{tabular}

(1): Fisher's exact test; (2): Kruskal-Wallis test; G1: kinesiotherapy; G2: kinesiotherapy and excitomotor electrotherapy; G3: kinesiotherapy and excitomotor electrotherapy and photobiomodulation.

Table 2. Cox regression model adjustments to estimate the relative risk of full recovery of movement in six months after PFP

\begin{tabular}{|c|c|c|c|c|c|c|c|}
\hline Variable & $\boldsymbol{\beta}$ estimate & SE & Wald test & $p$ & RR & \multicolumn{2}{|c|}{$\mathrm{Cl} 95 \%$} \\
\hline Age (years) & -0.01 & 0.01 & 0.7 & 0.404 & 0.99 & 0.97 & 1.01 \\
\hline Gender (male) & 0.24 & 0.48 & 0.25 & 0.618 & 1.27 & 0.49 & 3.28 \\
\hline Hypertension & -0.56 & 0.57 & 0.97 & 0.324 & 0.57 & 0.19 & 1.74 \\
\hline Diabetes Mellitus & 0.25 & 0.57 & 0.2 & 0.658 & 1.29 & 0.42 & 3.91 \\
\hline Smoking & -0.36 & 0.75 & 0.23 & 0.634 & 0.7 & 0.16 & 3.04 \\
\hline Hypercholesterolemia & -0.1 & 0.75 & 0.02 & 0.896 & 0.91 & 0.21 & 3.94 \\
\hline Prior PFP & -0.11 & 0.57 & 0.04 & 0.842 & 0.89 & 0.29 & 2.71 \\
\hline Wake up PFP & 0.38 & 0.48 & 0.62 & 0.431 & 1.46 & 0.57 & 3.78 \\
\hline Time between diagnosis and rehabilitation (days) ${ }^{(1)}$ & -0.01 & 0.01 & 0.74 & 0.388 & 0.99 & 0.98 & 1.01 \\
\hline Degree of PFP on admission & -0.35 & 0.17 & 4.41 & 0.036 & 0.7 & 0.51 & 0.98 \\
\hline
\end{tabular}

PFP: peripheral facial paralysis; SE: standard error; RR: relative risk; Cl: confidence interval.

Table 3. Cox multiple regression model adjusted to estimate the relative risk of full recovery of movement in six months due to the treatment received, adjusted by the effect of the degree of facial paralysis on admission

$\begin{array}{lccccc}\text { Variable } & \boldsymbol{B} & \mathrm{SE} & \mathrm{p} & \mathrm{RR} & \mathrm{Cl95 \%} \\ \text { Degree of PFP on admission } & -0.38 & 0.19 & 0.046 & 0.68 & 0.47 \\ \text { Treatment (Ref: Kinesiotherapy) } & 0.14 & 2 & & 0.99 \\ \text { kinesiotherapy+electrotherapy } & -0.26 & 0.85 & 0.763 & 0.77 & 0.15 \\ \text { kinesiotherapy+electrotherapy+photobiomodulation } & -0.03 & 1.01 & 0.980 & 0.98 & 0.14\end{array}$

PFP: peripheral facial paralysis; SE: standard error; RR: relative risk; Cl: confidence interval.

Table 4 reports the association between clinical and anthropometric characteristics and the face scale score. Longer time between the onset of PFP and the start of rehabilitation was associated with a lower face scale score for facial movement ( $r=-0.37 ; p=0.033)$. Sex was significantly associated with facial comfort such that women but not men exhibited significant improvement in the face scale score $(\mathrm{p}=0.034)$. Degree of paralysis was also associated with facial comfort such that a higher degree of paralysis was associated with lower facial comfort $(r=-0.44 ; p=0.010)$. Patients with hypertension had lower oral function scores $(\mathrm{p}=0.008)$, whereas patients with diabetes mellitus had lower ocular comfort scores $(p=0.003)$. Patients with a previous diagnosis of PFP had worse tear control ( $p=0.045)$. Degree of facial paralysis also was associated with social function such that a higher 
degree of paralysis was associated with lower social function $(r=-0.56 ; p=0.01)$. The total score on the face scale was associated only with the time to onset of rehabilitation such that longer time between the onset of PFP and the start of rehabilitation was associated with a lower total face scale score $(r=-0.37 ; p=0.035)$. There was no association between the type of physical therapy treatment and the scores obtained on each face scale domain.

Table 4. Associations between exposures and admission score with face scale domains

\begin{tabular}{|c|c|c|c|c|c|c|c|}
\hline Variables & $\begin{array}{c}\text { Facial } \\
\text { movements }\end{array}$ & $\begin{array}{l}\text { Facial } \\
\text { comfort }\end{array}$ & Oral Function & $\begin{array}{l}\text { Ocular } \\
\text { comfort }\end{array}$ & $\begin{array}{l}\text { Lacrimal } \\
\text { control }\end{array}$ & $\begin{array}{l}\text { Social } \\
\text { Function }\end{array}$ & Total \\
\hline Age (years) ${ }^{(1)}$ & $\begin{array}{r}r=0.10 \\
p=0.584\end{array}$ & $\begin{array}{r}r=-0.11 \\
p=0.559\end{array}$ & $\begin{array}{r}r=-0.11 \\
p=0.530\end{array}$ & $\begin{array}{r}r=-0.13 \\
p=0.465\end{array}$ & $\begin{array}{r}r=-0.2 \\
p=0.271\end{array}$ & $\begin{array}{r}r=0.02 \\
p=0.902\end{array}$ & $\begin{array}{l}r=-0.14 \\
p=0.441\end{array}$ \\
\hline Gender (female $\times$ male)(2) & 0.578 & $0.034^{+}$ & 0.427 & 0.626 & 0.423 & 0.936 & 0.538 \\
\hline Hypertension $\left(\right.$ no $\times$ yes) ${ }^{(2)}$ & 0.24 & $0.03^{+}$ & $0.008^{+}$ & 0.123 & 0.731 & 0.376 & 0.073 \\
\hline Diabetes Mellitus (no × yes)(2) & 0.743 & 0.978 & 0.331 & $0.003^{+}$ & 0.737 & 0.269 & 0.397 \\
\hline Smoking habit $($ no $\times$ yes)(2) & 0.343 & 0.834 & 0.263 & 0.263 & 0.252 & 0.29 & 0.96 \\
\hline Hypercholesterolemia (no $\times$ yes) ${ }^{(2)}$ & 0.513 & 0.211 & 0.085 & 0.16 & 0.145 & 0.117 & 0.29 \\
\hline Prior PFP $(\text { no } \times \text { yes) })^{(2)}$ & 0.734 & 0.96 & 0.134 & 0.721 & $0.045^{+}$ & 0.825 & 0.783 \\
\hline Wake up PFP $($ no $\times$ yes)(2) & 0.657 & 0.888 & 0.861 & 0.901 & 0.689 & 0.773 & 0.722 \\
\hline $\begin{array}{l}\text { Time between diagnosis and } \\
\text { rehabilitation (days) }\end{array}$ & $\begin{array}{r}r=-0.37^{+} \\
p=0.0338^{+}\end{array}$ & $\begin{array}{l}r=-0.27 \\
p=0.129\end{array}$ & $\begin{array}{r}r=-0.14 \\
p=0.422\end{array}$ & $\begin{array}{l}r=-0.24 \\
p=0.186\end{array}$ & $\begin{array}{l}r=-0.17 \\
p=0.33\end{array}$ & $\begin{array}{r}r=0.06 \\
p=0.757\end{array}$ & $\begin{array}{l}r=-0.37^{+} \\
p=0.035^{+}\end{array}$ \\
\hline Degree of PFP on admission ${ }^{(1)}$ & $\begin{array}{l}r=-0.18 \\
p=0.317\end{array}$ & $\begin{array}{r}r=-0.44^{+} \\
p=0.01^{+}\end{array}$ & $\begin{array}{l}r=-0.18 \\
p=0.316\end{array}$ & $\begin{array}{r}r=0.11 \\
p=0.537\end{array}$ & $\begin{array}{r}r=0.05 \\
p=0.793\end{array}$ & $\begin{array}{r}r=-0.56^{+} \\
p=0.01^{+}\end{array}$ & $\begin{array}{r}r=0.33 \\
p=0.064\end{array}$ \\
\hline
\end{tabular}

PFP: peripheral facial paralysis; ("): Spearman correlation; (2): Mann-Whitney; t: factors associated with face scale domains.

\section{DISCUSSION}

In this study, the prognosis for recovery was significantly associated with PFP degree. This finding is consistent with other studies that have reported an influence of initial paralysis severity on prognosis ${ }^{28}$. One strength of this study is that we assessed the House-Brackmann scale both at the initial visit and after 6 months of treatment to establish the final recovery of the patient. The advantages of the House-Brackmann scale is that it is commonly used during the initial evaluation of PFP, it is easy to use, helps to establish the prognosis, and allows the assessment of the face during both movement and rest. The House-Brackmann scale is comparable to other scales to assess facial paralysis, and is being adopted as the gold standard by the Facial Nerve Disorders Committee of the American Academy of Otolaryngology - Head and Neck Surgery ${ }^{29,30}$. The evaluations of functional outcomes were conducted at 6-month follow-up because it is established as a period of optimal plasticity and used in different clinical studies.

In this study, the effect of treatment was not significantly different across treatment types for either the primary or secondary outcomes. Several physical therapy techniques are used for the treatment of PFP, including biofeedback, self-massage, relaxation, and electrotherapy, to restore trophism, muscle strength, and function. Prior studies have compared the use of electrical stimulation to isolated therapeutic exercise and found that neither treatment type exhibited statistical superiority in terms of complete facial recovery. In addition, the literature has not established the amount of exercise (and thus the amount of facial nuclear hyperexcitability or regeneration of aberrant nerve fibers) that could lead to consequences such as synkinesis and facial spasm ${ }^{30,31}$.

The face scale is a validated instrument and has been used to quantify the association between PFP and quality of life in patients. A lower score on the facial movement domain of the face scale was associated with a higher degree of facial paralysis at initial evaluation. This result is consistent with a previous study, in which higher scores on the House-Brackmann scale were associated with lower facial movement ${ }^{32}$. That study also found that muscle strength at diagnosis was associated with long-term poor motor control.

A study by Kleiss et al. ${ }^{31}$ found that women were more psychologically affected by PFP and less satisfied with their appearance, leading to reduced social interaction and psychosocial dysfunction. In our study, women had lower scores on the facial comfort domain, which is consistent with the prior study and is believed to be due to the higher aesthetic demands of women.

A retrospective study observed that lagophthalmos and keratitis (tearing), which is also known as Bogorad syndrome or "crocodile tears", is a major eye complication after PFP. In this study, we found that the score on the tear control domain of the face scale was lower when the patient had previous facial paralysis ${ }^{32}$. Patients were not 
classified according to the topography of the facial nerve, but we can infer that the amount of facial paralysis may be related to a greater number of topographies in the path of the facial nerve, which is more likely to affect the lacrimal system.

Our study also found that social function was associated with the degree of paralysis such that a higher degree of paralysis was associated with worse social outcomes. Several studies corroborate this finding, highlighting the psychological and social impact of PFP on patients. PFP may affect social relationships, self-esteem, public behavior, work performance, and interpersonal communication, generating conflicting depressive feelings and leading to isolation and poor quality of life ${ }^{32}$.

The influence of diabetes mellitus and hypertension on the PFP prognosis are still unclear, but these clinical factors were associated with face scale domains in our study. Some authors reported a less favorable outcome for PFP in diabetic patients showing a clinical total palsy in $76 \%$ of diabetics and $45 \%$ of non-diabetics, and more denervation rate. Recent studies showed a no correlation between the duration of diabetes and the clinical severity of the $\mathrm{PFP}^{33-35}$. Hypertension can be the cause of facial paralysis. The appearance of an idiopathic $\mathrm{PFP}$ in combination with psychological stress may give rise to a hypertensive state. Vascular spasm and local edema can, in that case, influence oxygen and nutrient supply to the facial nerve ${ }^{36}$.

The main limitations of this study are its small sample size, the lack of patient randomization, the lack of analysis of electrophysiological findings, and the absence of synkinesis and facial spasm reports after the follow up. One strength of this study is that it is one of the few studies in Latin America to investigate prognostic factors and major treatments associated with the functional outcome of patients with PFP.

\section{CONCLUSION}

In conclusion, our results indicate that all modalities in this study showed the same result in PFP. Recovery of $\mathrm{PFP}$ was associated with several factors, including degree of nerve dysfunction, length of time to onset of rehabilitation, sex, hypertension, diabetes mellitus, and previous PFP, all of which were associated with worse outcomes in the face scale. Different treatment methods should be further evaluated through randomized clinical trials.

\section{REFERENCES}

1. Lee DH. Clinical efficacy of electroneurography in acute facial paralysis. J Audiol Otol. 2016;20(1):8-12. doi: 10.7874/ jao.2016.20.1.8

2. Finsterer J. Management of peripheral facial nerve palsy. Eur Arch Otorhinolaryngol. 2008;265:743-52. doi: 10.1007/ s00405-008-0646-4

3. Bélec L, Gherardi R, Georges AJ, Schüller E, Vuillecard E, Di Costanzo B, Martin PM. Peripheral facial paralysis and HIV infection: report of four African cases and review of the literature. J Neurol. 1989:236:411-4.

4. Vakharia K, Vakharia K. Bell's Palsy. Facial Plast Surg Clin North Am. 2016;24(1):1-10. doi: 10.1016/j.fsc.2015.08.001

5. Peitersen E. Bell's palsy: the spontaneous course of 2,500 peripheral facial nerve palsies of different etiologies. Acta Otolaryngol Suppl. 2002;549:4-30.

6. Jowett N. A general approach to facial palsy. Otolaryngol Clin North Am. 2018;51(6):1019-31. doi: 10.1016/j.otc.2018.07.002

7. Hohman MH, Hadlock TA. Etiology, diagnosis, and management of facial palsy: 2000 patients at a facial nerve center. Laryngoscope. 2014;124(7):E283-93. doi: 10.1002/lary.24542

8. Eviston TJ, Croxson GR, Kennedy PG, Hadlock T, Krishnan AV. Bell's palsy: aetiology, clinical features and multidisciplinary care. J Neurol Neurosurg Psychiatry. 2015;86(12):1356-61. doi: 10.1136/jnnp-2014-309563

9. Marenda SA, Olsson JE. The evaluation of facial paralysis. Otolaryngol Clin North Am. 1997;30(5):669-82.

10. Yeo SW, Lee DH, Jun BC, Chang KH, Park YS. Analysis of prognostic factors in Bell's palsy and Ramsay Hunt syndrome. Auris Nasus Larynx. 2007:34:159-64. doi: 10.1016/j.anl.2006.09.005

11. Sillman JS, Niparko JK, Lee SS, Kileny PR. Prognostic value of evoked and standard electromyography in acute facial paralysis. Otolaryngol Head Neck Surg. 1992;107(3):377-81. doi: 10.1177/019459989210700306

12. Veillon F, Taboada LR, Eid MA, Riehm S, Derby C, Schultz P, Charpiot A. Pathology of the facial nerve. Neuroimag Clin N Am. 2008;18:309-320. doi: 10.1016/j.nic.2008.01.002

13. Baugh RF, Basura GJ, Ishii LE, Schwartz SR, Drumheller CM, Burkholder R, et al. Clinical practice guideline: Bell's palsy. Otolaryngol Head Neck Surg. 2013;149 Suppl 3:S1-27. doi: 10.1177/0194599813505967

14. Kubik M, Robles L, Kung D. Familial Bell's palsy: a case report and literature review. Case Rep Neurol Med. 2013;1-3. doi: 10.1155/2012/674981

15. Almeida MAM. Paralisia facial periférica em Petrópolis. Arq NeuroPsiquiat. 1992:50:60-4. doi: 10.1590/S0004-282X1992000100011

16. Campbell K, Brundage J. Effects of climate, latitude, and season on the incidence of Bell's Palsy in the US Armed Forces, October 1997 to September 1999. Am J Epidemiol. 2002;156:32-39. doi: 10.1093/aje/kwf009

17. Beurskens $\mathrm{CH}$, Heymans PG. Physiotherapy in patients with facial nerve paresis: description of outcomes. Am J Otolaryngol. 2004;25(6):394-400. doi: 10.1016/j.amjoto.2004.04.010 
18. Cronin GW, Steenerson RL. The effectiveness of neuromuscular facial retraining combined whit electromyography in facial paralysis rehabilitation. Otolaryngol Head Neck Surg. 2003;128(4):534-8. doi: 10.1016/S0194-59980300005-6

19. Beurskens $\mathrm{CH}$, Heymans PG. Positive effects of mime therapy on sequelae of facial paralysis: stiffness, lip mobility, and social and physical aspects of facial disability. Otol Neurotol. 2003;24(4):677-81. doi: 10.1097/00129492-200307000-00024

20. Cederwall E, Olsen MF, Hanner P, Fogdestam I. Evaluation of a physiotherapeutic treatment intervention in "Bell's" facial palsy. Physiother Theory Pract. 2006;22(1):43-52. doi: 10.1080/09593980500422529

21. Shafshak TF. The treatment of facial palsy from the point of view of physical and rehabilitation medicine. Eura Medicophys. 2006;42(1):41-7.

22. Fonseca KM, Mourão AM, Motta AR, Vicente LC. Scales of degree of facial paralysis: analysis of agreement. Braz J Otorhinolaryngol. 2015;81(3):288-93. doi: 10.1016/j.bjorl.2014.04.005

23. Kahn JB, Gliklich RE, Boyev KP, Stewart MG, Metson RB, McKenna MJ. Validation of a patient-graded instrument for facial nerve paralysis: the FaCE scale. Laryngoscope. 2001;111(3):387-98. doi: 10.1097/00005537-200103000-00005

24. Manikandan N. Effect of facial neuromuscular re-education on facial symmetry in patients with Bell's palsy: a randomized controlled trial. Clin Rehabil. 2007;21:338-343. doi: 10.1177/0269215507070790

25. Carvalho AR, Fungueto EM, Canzi IM, Barbieiro C, Moraes V, Bertolini GRF, Aragão FA. Correntes diadinâmicas de Bernard e iontoforese no tratamento da dor lombar. Fisioter Mov. 2005;18(4):11-9.

26. Artioli DP, Eloísa Sanches PN, Santos JC, Celeste LFN, Santini L, Junior MCA, et al. Using polarized current in Physiotherapy. Rev Bras Clin Med. 2011;9(6):428-31.

27. Bernal G. Helium neon and diode laser therapy is an effective adjunctive therapy for facial paralysis. Laser Ther. 1993;5:79-87.
28. Almeida JR, Guyatt GH, Sud S, Dorion J, Hill MD, Kolber MR, et al. Management of Bell palsy: clinical practice guideline. CMAJ. 2014;186(12):917-22. doi: 10.1503/cmaj.131801

29. Fonseca KMO, Mourão AM, Motta AR, Vicente LCC. Scales of degree of facial paralysis: analysis of agreement. Braz J Otorhinolaryngol. 2015;81:288-93. doi: 10.1016/j.bjorl.2014.04.005

30. Alakram P, Puckree T. Effects of electrical stimulation on HouseBrackmann scores in early Bell's palsy. Physiother Theory Pract. 2010;26(3):160-6. doi: 10.3109/09593980902886339

31. Kleiss IJ, Hohman MH, Susarla SM, Marres HAM, Hadlock TA. Health-related quality of life in 794 patients with a peripheral facial palsy using the FaCE Scale: a retrospective cohort study. Clin Otolaryngol. 2015;40:651-6. doi: 10.1111/coa.12434

32. Tavares-Brito J, van Veen MM, Dusseldorp JR, Bahmad F Jr, Hadlock TA. Facial Palsy-Specific Quality of Life in 920 Patients: Correlation With Clinician-Graded Severity and Predicting Factors. Laryngoscope. 2019;129(1):100-4. doi: 10.1002/ lary.27481

33. Adour KK, Douglas NB, Wingerd J. Bell palsy, dilemma of diabetes mellitus. Arch Otolaryngol. 1974;99(2):114-7. doi: 10.1001/archotol.1974.00780030120009

34. Al-Azawi LM, Mirza KB. The usefulness of the brainstem auditory evoked potential in the early diagnosis of cranial nerve neuropathy associated with diabetes mellitus. Electromyogr. Clin Neurophysiol. 2004;44(7):387-94.

35. Kiziltan ME, Uluduz D, Yaman M, Uzun N. Electrophysiological findings of acute peripheral facial palsy in diabetic and non-diabetic patients. Neurosci Lett. 2007;418(3):222-6. doi: 10.1016/j.neulet.2007.03.028

36. Abraham-Inpijn L, Oosting J, Hart AAM. Bell's palsy: factors affecting the prognosis in 200 patients with reference to hypertension and diabetes mellitus. Clin Otolaryngol. 1987;12(5):349-55. doi: 10.1111/j.1365-2273.1987.tb00215.x 